\title{
INFLUENCE OF LEACHATES ON GEOTEHNICAL AND GEOCHEMICAL PROPERTIES OF TERMITE MOUND SOILS
}

\author{
Adebola Adekunle ${ }^{{ }^{*}}$, Fidelis Nkeshita ${ }^{1}$, Adetayo Akinsanya ${ }^{1}$ \\ ${ }^{1}$ Department of Civil Engineering, Federal University of Agriculture, Abeokuta, Nigeria \\ * E-mail of corresponding author: adebolamay@gmail.com
}

\begin{abstract}
This study investigated the influence of leachate prepared from Telfairia occidentalis on the geotechnical and geochemical properties of termite mound soil obtained from the premises of the federal university of agriculture, Abeokuta, south-western Nigeria. The termite mound soil samples were collected from three different locations and each sample collected was contaminated by mixing with leachates in percentage increments of $0 \% 10 \%, 15 \%$ and $20 \%$ of dry weight of the air-dried soil. The soil samples were subjected to Atterberg limits and hydraulic conductivity tests for geotechnical observation and Xray fluorescence tests for geochemical tests. The range of values for the geotechnical analyses were obtained as; plastic limit $(9.1 \%-14.2 \%)$, liquid limit $(28.6 \%-61 \%)$, plasticity index $\left((18.2 \%-49.5 \%)\right.$ and hydraulic conductivity $\left(1.85-4.1 \times 10^{-8}\right)$ $\mathrm{cm} / \mathrm{sec}$ ) with a resultant reduction in the plastic limit, liquid limit and plasticity index values but an increase in the hydraulic conductivity of the samples as the leachate concentration increased. The results from X-ray fluorescence analyses after $20 \%$ leachate contamination showed that the major elemental chemical composition for the three samples were comprised of $\mathrm{SiO}_{2}$ (56.25 - 56.5\%), $\mathrm{Al}_{2} \mathrm{O}_{3}(28.42-28.50 \%), \mathrm{Fe}_{2} \mathrm{O}_{3}(4.46-6.5 \%), \mathrm{TiO}_{2}(1.08-1.23 \%), \mathrm{CaO}(1.45-1.60 \%), \mathrm{P}_{2} \mathrm{O}_{5}(0-0.04 \%)$, $\mathrm{K}_{2} \mathrm{O}(0.9-6.1 \%)$ and $\mathrm{MnO}(0.02-4.7 \%)$. There was a marginal alteration of the indices with the values inferring the presence of a minimum composition of feldspar and a major composition of quartz-rich minerals and thus lending more credence to the presence of silicates as shown from the X-ray fluorescence results. It also infers that the termite mounds are predominantly made from sand materials. The termite soil samples obtained from the aforementioned locations may not be suitable for engineering works unless stabilization procedure is adopted.
\end{abstract}

Keywords Geotechnical, Geochemistry, Termite mound, Leachates

\begin{tabular}{c}
\hline $\begin{array}{c}\text { Received: } 20.10 .2020 . / \text { Accepted: 09.07.2021. } \\
\text { Published online: 01.12.2021. }\end{array}$ \\
\hline $\begin{array}{c}\text { Original scientific paper } \\
\text { https://oi.org/10.37023/ee.8.1-2.4 }\end{array}$
\end{tabular}

\section{INTRODUCTION}

Termites are social insects in which a vast majority of its species rely on soil for feeding. Termite mounds are formed when a ground nest enlarges above the initial concealing surface. These mounds form when Termites cement the soil particles with the aid of secretions from saliva and excrement. These hills appear to persevere against harsh weather conditions over a long period of time (Eggleton, 2000; Ramesh et al., 2016). These termite activities ensure that the mound produced differ in physical and chemical properties from adjacent soils with a clay content of up to $20 \%$ than that of the adjacent soil, indicating a preference by the termites for smaller clay particles for construction. The mounds produced has cohesive properties and mechanical strength and has a lot of applications for use such as in improving soil stability and lawn tennis clay courts. (Muddaraju, H.C. and Sunita, 2019; Felix et al., 2000; Samuel et al., 2016).

Leachates are liquid substances containing solid particles usually formed from the degradation of organic wastes and when water seeps down through solid wastes undergoing decomposition. If this process is not carefully controlled, it can cause surface and groundwater contamination (Nta and Odiong, 2017; Aderemi et al., 2011). It is therefore necessary that landfill sites where leachates may be formed are properly lined with materials that can prevent pollutants from percolating into groundwater. The presence of Leachates in soil can alter the chemical and mechanical properties of that soil. In a study carried out by Nayak et al. (2010), the Atterberg's limit, Proctor test and permeability values were altered for a $0.5 \mathrm{M} \mathrm{NaCl}$ modified soil with percentage increments of 0,20 , etc. Another study showed that there was an alteration in the mechanical properties of a leachate contaminated soil in terms of liquid limit, specific gravity and direct shear strength when compared to the uncontaminated soils (Sunil et al., 2006). This study focused on the influence of percentage proportions of an artificially prepared leachate on the mechanical behaviour of termite hill soil samples under varying temperatures. 


\section{MATERIALS AND METHODS}

\subsection{Preparation of Samples}

Samples of termite mound were collected from three different locations within the campus of the Federal University of Agriculture, Abeokuta, and South-western Nigeria for the experimental study and was prepared in accordance with BS $1371-1: 1990$. The coordinates for the sites are Latitude $7.23^{\circ} \mathrm{N}$ Longitudes $3.43^{\circ} \mathrm{E}, 7.23^{\circ} \mathrm{N}$, $3.44^{\circ} \mathrm{E}$ and $7.23^{\circ} \mathrm{N}, 3.43^{\circ} \mathrm{E}$. The bulk samples were transported in polythene bags to the laboratory. Leachate samples were prepared in the laboratory by subjecting a collection of the vegetable plant Telfairia occidentalis to decomposition for up to six weeks under anaerobic conditions in a sealed container.

The termite mound samples were air dried for a few days according to the procedure adopted by Harun et al. (2013). The soil samples were subsequently crushed manually and then allowed to pass through a $4.75 \mathrm{~mm}$ sieve. The air-dried samples were then mixed with the prepared artificial leachates in percentage increments of $0 \% 10 \%$, $15 \%$ and $20 \%$ of dry weight of the air-dried soil. The mixtures were stored in airtight containers in order to cure for two weeks thereby achieving certain biochemical properties that would be similar to that under real in-situ conditions. After the period for curing, the mixed samples were transferred to an incubator, with temperature set to $40^{\circ} \mathrm{C}$, the samples were left at this temperature for a period of 8 hours each day for 30 days to simulate biochemical conditions.

\subsection{Experimental Procedures}

After the duration of this temperature treatment, the mixed samples were subjected to geotechnical tests including specific gravity test, Atterberg limit tests, compaction test and hydraulic conductivity test.

Specific gravity test carried out according to B.S. 1377:1990, part 2:8; For the Atterberg limit test, it was carried out according to B.S. 1377:1990, part 2:4, 2:5. The liquid limit test was carried out by placing a portion of the contaminated termite mound soil paste on the Casagrande apparatus with a groove of about $2 \mathrm{~mm}$ wide cut made down its centre to separate it into two halves in the paste and subsequently subjected to shallow drop of the cup. The number of such blows cause the two soil halves to come together over a distance of $13 \mathrm{~mm}$ and soil sample is taken for the determination of the moisture content of the soil. Moisture content was plotted against the number of blows and a straight line was drawn to pass through each of the plotted points. The plastic limit was determined by preparing a stiff paste of the contaminated sample on a glass plate which was subsequently rolled out manually using a back-and-forth movement to produce a uniform thread about $3 \mathrm{~mm}$ diameter without crumbling. The plasticity index was determined as the numerical difference between the liquid limit and the plastic limit.

Compaction test was carried out on the leachate contaminated termite mound soil according to B.S. 1377:1990, part 4:4 by adopting the Proctor standard compaction test. This involved the soil samples being compacted in three layers with each layer subjected to blows from a $4.5 \mathrm{~kg}$ hammer which administered the blows over the surface of the sample placed in a cylindrical metal mould of about $105 \mathrm{~mm}$ in diameter and approximately $115.5 \mathrm{~mm}$ in height.

The head permeability test was adopted for this study according to B.S. 1377:1990, part 5:5 in which uncontaminated and contaminated soil samples to study the hydraulic conductivity compacted to standard Proctor maximum dry density in the permeability mould (Sunil et al, 2006). Filter paper was used to prevent clogging of the perforated discs by the fine soil particles by being placed on each face of the soil sample. Nuts were fastened and the permeameter assembled properly after placing its top and bottom plates. The permeameter was linked to a standpipe which was filled with distilled water when the $0 \%$ contaminated sample was tested and leachate when the $20 \%$ contaminated sample was tested. The soil was saturated by allowing distilled water/leachate to flow continuously through the sample from the standpipe.

$\mathrm{X}$-ray fluorescence (XRF) analyses were carried out on the series of mixed samples after the temperature treatment in order to investigate the mineralogical components of the soil samples before contamination (at $0 \%)$ and after contamination (at $20 \%$ ).

\section{RESULTS AND DISCUSSION}

\subsection{Atterberg Limits}

Figures $1-\mathbf{3}$ shows the variations of plastic limit, liquid limit and plasticity indices respectively with percentage increase in leachate contamination. The range of values for plastic limit for the samples varied from $9.1 \%-14.2 \%$ for the range of leachates exposure. There was a general reduction in plastic limit of the samples within the range of $0 \%$ to $20 \%$ leachate concentration with all three samples with a marginal increase/decrease in values at the $10 \%$ and $15 \%$ leachate concentrations. It is worthy to note that sample 1 had the lowest plastic limit values all through the percentage leachate contamination phases. The low values of plastic limit exhibited by the termite mound samples at $0 \%$ contamination indicate a low percentage of clay fines contained within the mound collected in which it is predominantly made up of fine to medium grain sands. 


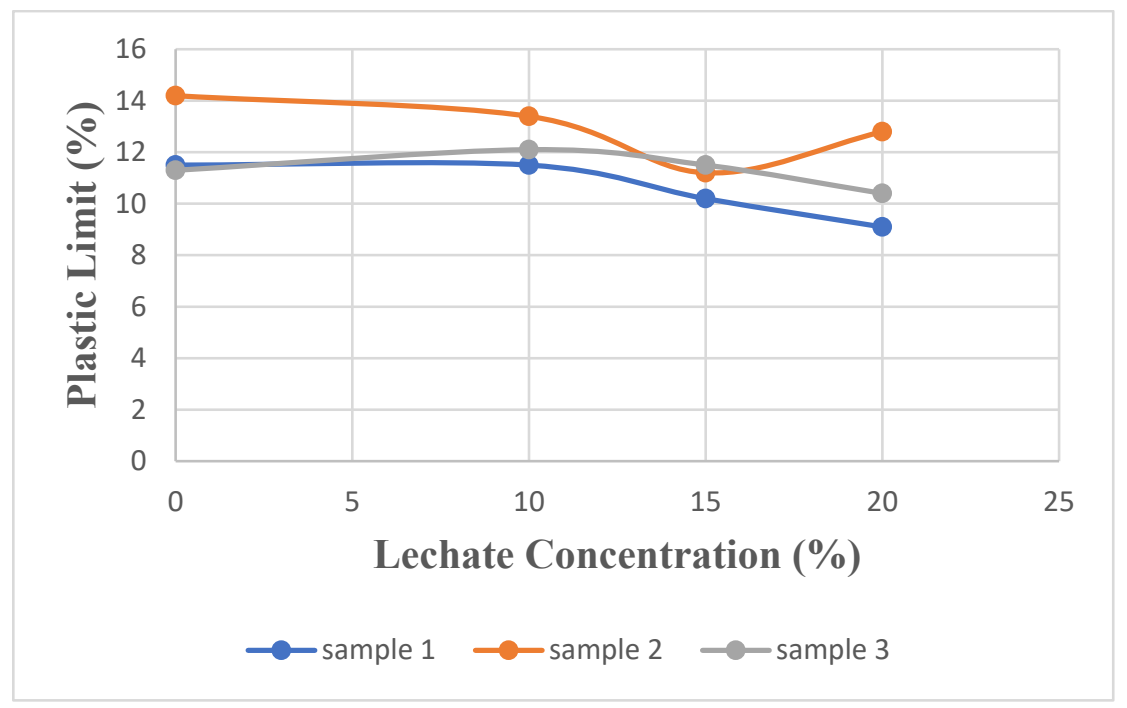

Figure 1. Plastic limit of termite mound-leachate concentration

The liquid limit results for the three contaminated samples ranged from $28.6 \%-61 \%$. The liquid limit showed a decreasing trend as the percentage concentration of leachates increased. The same trend could be observed for the plasticity index $(18.2 \%-49.5 \%)$ which resulted from the marginal differences in the values of the plastic limits of the samples. These types of trends were also observed in the study carried out by Harun et al. (2013) while observing the influence of leachates on sandy clay soil and in Sunil et al. (2006) while observing the strength and chemical characteristics on leachates on lateritic soils. The clay content of the samples as well as the chemical constituents of the leachates may have played an influential role on the behaviour of the samples. According to Das in (1994), clay minerals exhibit electrochemical properties thereby possessing charged particles and a subsequent affinity for attracting opposite charges of water molecules which are naturally dipolar. Leachates are liquid based and contains different categories of contaminants including dissolved organic components such as alcohols, inorganic compounds such as cations e.g. iron and anions e.g. chlorides and heavy metals (Christensen et al., 1994). As the percentage leachate concentration increased, the water content reduces and this result in the reduction of its ability to react with the clay particles. There would thus be a reduction in the liquid limit and plasticity index values.

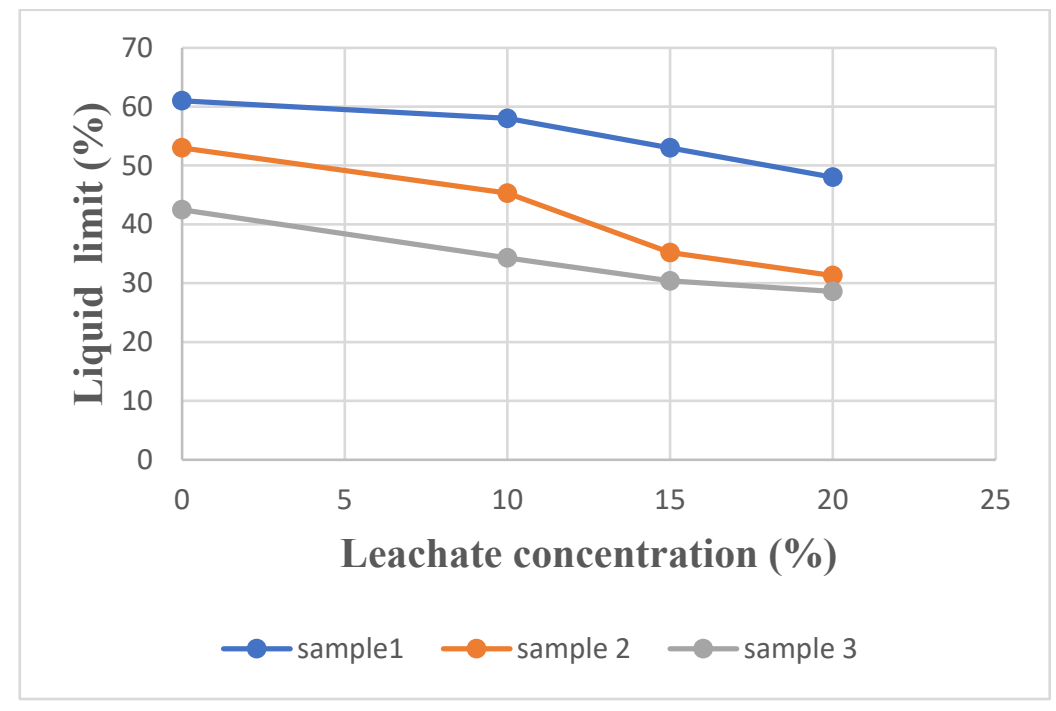

Figure 2. Liquid limit of termite mound-leachate concentration 


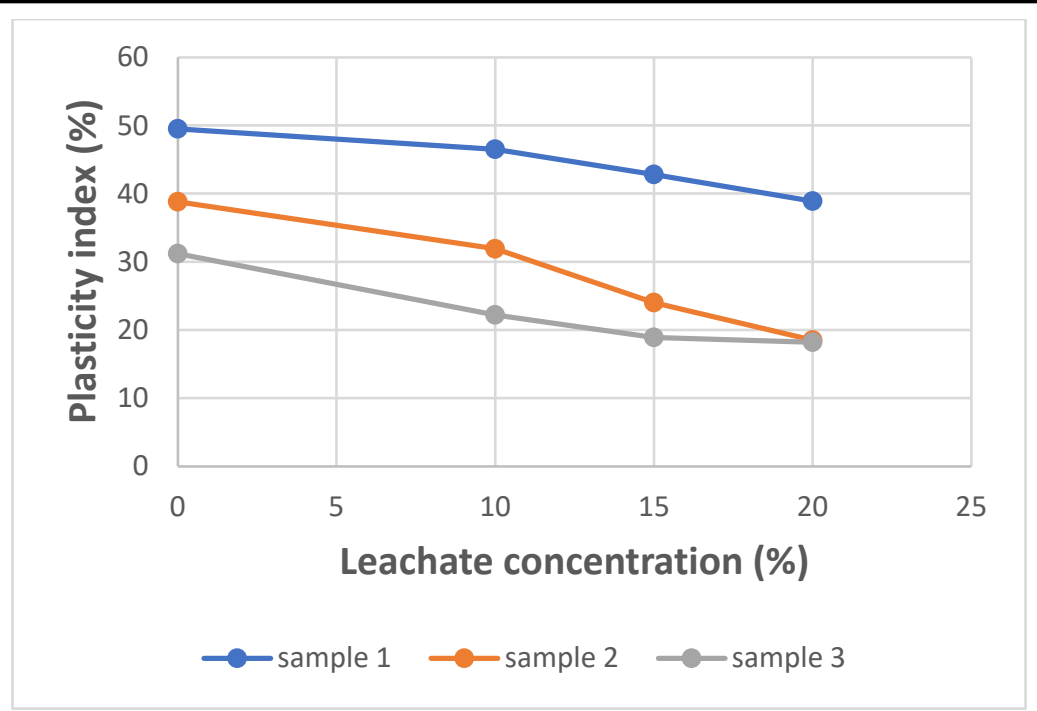

Figure 3. Plasticity index of termite mound-leachate concentration

\subsection{Hydraulic Conductivity}

There was an increase in the value of permeability of the termite mound samples as the percentage leachate contamination increased after heat treatment as can be seen from Figure 4 with a range of $1.85-4.1 \cdot 10^{-8} \mathrm{~cm} / \mathrm{sec}$. Sample 2 showed a spike in the permeability values after the $10 \%$ leachate contamination. This can be attributed to the chemical reactions that may have taken place between the leachate and mineral content of clay in the samples as well as the heat treatment probably showing its aftereffects. In a study conducted by Sunil et al. (2008) on soilleachate reaction, there was a similar trend of an increase in permeability resulting from increase in leachate concentration. The cementing agents from the activities of termites may have helped to bind fine particles to create aggregates. These aggregates may be destroyed when particles are exposed to acidic or basic conditions. The mineral contents from clay that are contained in the termite mound may also be dissolved by the action of acidic/basic agents (Uppot and Stephenson, 1989; Sunil et al., 2006 and Sridharan, 1981). The leachate may have dissolved the clay mineral contents and thus increased the effective pore space leading to an increase in hydraulic conductivity. The results also show that that there were lower values of Plastic limit and Liquid Limit as the permeability increases except in the case of the PL of sample which showed an inverse trend. It is possible that the biochemical processes that may have occurred due to the activities of termites in addition to its reaction with the leachate, may have influenced this trend. Leachates contain organic components, and this may also account for the geotechnical properties exhibited by the samples. It is in agreement with the study conducted by AlimohammadiJelodar and Karimpour-Fard (2018) in which it reported that Permeability can be influenced by the physical and chemical properties of the permeating fluid and the soil including the organic compositions and clay minerals. It further reported that clay of higher Liquid Limit and Plastic Limit showed lower values of permeability as against the passage of all the organic fluids that were used in the study even though the rate of decrease varied from fluid to fluid and that on increasing soil plasticity, there was corresponding reduction of permeability.

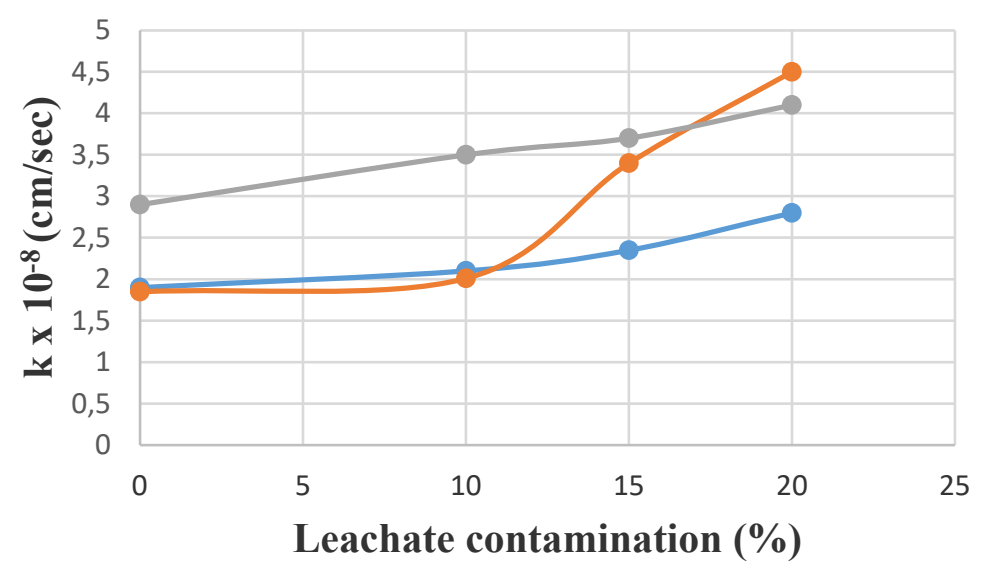

-sample $1 \longrightarrow$ sample $2 \longrightarrow$ sample 3

Figure 4: Hydraulic conductivity of termite mound-leachate concentration 


\subsection{Elemental Geochemistry and Geochemical Indices}

The XRF results for the three termite mound samples after heat treatment and for values before $(0 \%)$ and after (20\%) leachate contamination is shown in Table 1 below. A cursory look at these results shows that there were marginal alterations from the original values of the elements after contamination. This could be attributed to chemical reactions that may have taken place between the soil samples and leachates. The predominant elements are $\mathrm{Al} 2 \mathrm{O} 3$ and $\mathrm{Fe} 2 \mathrm{O} 3$. The use of certain geochemical indices such as $\mathrm{K} 2 \mathrm{O} / \mathrm{Al} 2 \mathrm{O} 3, \mathrm{~K} 2 \mathrm{O} / \mathrm{CaO}$ and $\mathrm{Al} 2 \mathrm{O} 3 / \mathrm{TiO} 2$ have been previously reported in literature (Momah and Okieimen, 2020).

Table 1: XRF result of the major Elemental Composition of termite mound soils

\begin{tabular}{|c|c|c|c|c|c|c|c|}
\hline & & \multicolumn{2}{|c|}{ Sample 1 } & \multicolumn{3}{c|}{ Sample 2 } & \multicolumn{2}{c|}{ Sample 3 } \\
\hline $\mathrm{S} / \mathrm{N}$ & Element & $0 \%$ & $20 \%$ & $0 \%$ & $20 \%$ & $0 \%$ & $20 \%$ \\
\hline 1 & $\mathrm{AI}_{2} \mathrm{O}_{3}$ & 55.39 & 56.5 & 56.26 & 56.3 & 54.82 & 56.4 \\
\hline 2 & $\mathrm{Fe}_{2} \mathrm{O}_{3}$ & 30.06 & 28.42 & 29.22 & 28.52 & 31.23 & 22.5 \\
\hline 3 & $\mathrm{TiO}_{2}$ & 4.46 & 4.46 & 4.95 & 5.65 & 4.98 & 6.5 \\
\hline 4 & $\mathrm{CaO}$ & 1.33 & 1.23 & 1.25 & 1.25 & 1.23 & 1.08 \\
\hline 5 & $\mathrm{P}_{2} \mathrm{O}_{5}$ & 1.65 & 1.45 & 1.55 & 1.5 & 1.61 & 1.6 \\
\hline 6 & $\mathrm{~K}_{2} \mathrm{O}$ & - & 0.05 & 0.04 & 0.05 & 0.04 & 0.02 \\
\hline 7 & $\mathrm{MnO}$ & 0.89 & 6.01 & 0.98 & 0.96 & 0.85 & 0.9 \\
\hline
\end{tabular}

In a study conducted by Cox et al., (1995), the authors used the ratio of the indices $\mathrm{K}_{2} \mathrm{O} / \mathrm{Al}_{2} \mathrm{O}_{3}$ to establish the dominance of feldspar in relation to other minerals contained in mudstone with indications showing that values greater than 0.5 as predominantly composed of alkali K-feldspar and values below 0.4 inferring to a minimum composition of feldspar in the original mudstone. The ratio of the indices $\mathrm{K}_{2} \mathrm{O} / \mathrm{Al}_{2} \mathrm{O}_{3}$ obtained for the leachate contaminated soil samples were all below 0.4 with a range of $(0.02-0.26)$ thus inferring a minimum composition of feldspar. These results are like what was obtained in a study conducted by Momah and Okieimen (2020) on termite mound in Ika area in Delta State, South-south region of Nigeria.

The values of this index that was obtained for the leachate contaminated termite mound soil were in the range of $(1.97-2.1)$ thus inferring that the samples were quartz rich with a high-ratio of sandstones with minimum composition of clay minerals. These results when compared to what was obtained in the study by Momah and Okieimen (2020) were similar even though this study obtained higher index values.

\section{CONCLUSION}

The study was carried out to determine the influence of leachates on certain geotechnical and chemical properties of termite mound soil contaminated with a synthetic leachate made from the plant, Telfairia occidentalis. The leachate contamination was shown to have altered the Atterberg limits, hydraulic conductivity as well as the geochemical attributes of the soil mixture.

The result of the study indicates that there was reduction in the plastic limit, liquid limit, and plasticity index values as the concentration of leachates increased. The hydraulic conductivity of the samples was also shown to have increased as the leachate concentration increased.

The geochemical indices resulting from the XRF results show that there was a marginal alteration of the indices showing the presence of a minimum composition of feldspar and a major composition of quartz-rich minerals lending more credence to the presence of silicates as shown from the X-ray fluorescence results. It also infers that the termite mounds are predominantly made from sand materials.

The implication is that when these soils from termite mounds are modified by leachates of organic origin, it may lead to serious geotechnical challenges such as erosion, ground subsidence, seepage in landfills, etc. Thus, the soil sample obtained from this source may not be suitable for engineering works unless stabilization procedure is adopted. 


\section{REFERENCES}

Aderemi AO, Oriaku AV, Adewumi GA, Otitoloju AA. Assessment of groundwater contamination by leachate near a municipal solid waste landfill. Afr. J. Environ. Sci. Technol. 2011; 5:933-940.

Alimohammadi-jelodar, S, Karimpour-fard, M. Permeability of two clayey soils exposed to petroleum products and Organic Solvents Civil Engineering Infrastructures Journal, svez. 51(1), pp. 131-146, 2018.

British Standard Institution, Methods of test for soils for civil engineering purposes, BS 1377 (1990).

British Standard Institution 1377, Methods of Test for Soil for Civil Engineering Purposes-Part 2: Classification Tests, BS1377, London, ISBN: 0580178676, pp. 68, 1990.

Christensen, T. H., Kjeldsen, P., Albrechtsen, H. J., Heron, G., Nielsen, P. H., Bjerg, P. L. and Holm, P. E. Crit. Rev. Environ.Sci. Technol. 24, 119-202 (1994).

Cox R, Lower DR, Cullers RL (1995). Influence of sediment recycling and basement evolution of mudrock chemistry in the Southeastern United States Geochimica et Cosmochimica Acta 59:2919-2940

Das, B. M. Principle of Geotechnical Engineering, 3rd edition, PWS Publishing Company, 436 pp., 1994.

Eggleton, P. (2000). Global patterns of termite diversity. In T. Abe, D.E. Bignell \& M. Higashi (Eds.), Termites: evolution, sociality, symbioses and ecology (pp. 25-51). Dordrecht: Kluwer Academic Publishing.

Felix F.U., Alu O. C, and Sulaiman, J. (2000). "Mound soil as construction material". J. Mater. Civ. Eng., 2000, ASCE 12(3): 205-211.

Harun, S. N., Ali Rahman, Z., Rahim, S. A., Lihan, T. and Idris, W. M. R. "Effects of Leachate on Geotechnical Characteristics of Sandy Clay Soil”. AIP Conference Proceedings 1571, 530 (2013)

Momah, M and Okieimen, F. E. "Minerology, geochemical composition and geotechnical properties of termite mound soil". Journal of Ecology and The Natural Environment. Vol. 12(1), pp. 1-8, January-March 2020.

Muddaraju, H.C. and Sunita, 2019. "Study on Geotechnical Properties of Red Termite Mound Soil". International Journal of Scientific \& Engineering Research Volume 10, Issue 12, December-2010. (2010).

Nayak, S, Sunil, B, Shirhari, S and Sivapullaiah, P. Geotechnical and Geological Engineering 28 (6), 899-906

Nta SA, Odiong IC. Impact of municipal solid waste landfill leachate on soil properties in the dumpsite (A case study of Eket Local Government Area of Akwa Ibom State, Nigeria). Int. J. Sci. Eng. Sci. 2017; 1:5-7.

Ramesh K. Kandasami, Renee M. Borges, Tejas G. Murthy, "Effect of biocementation on the strength and stability of termite mounds", The International Journal of Engineering and Science, vol. 3, no. EG2, pp.99-113, 2016.

Samuel Assam, Fidelis Okafor and UmohUmoh. (2016). "Potentials of Processed Termite as a Stabilizing Agent in Clay Soil". IOSR Journal of Mechanical and Civil Engineering (IOSR-JMCE) e-ISSN: 2278-1684, pISSN: 2320-334X, Volume 13, Issue 4 Ver. I (Jul. - Aug. 2016), PP 40-50 Nigeria.

Sridharan, A., Nagaraj, T.S., Sivapullaiah, P.V. 1981. Heaving of soil due to acid contamination. Proc. of International Conference on Soil Mechanics Foundation Engineering, vol. 2, 383-386. Stockholm.

Sunil, B. M. S., Shrihari and Nayak, S. (2006) Effect of $\mathrm{pH}$ on the geotechnical properties of laterite Journal of Engineering Geology 106:20-25.

Sunil, B. M. S., Shrihari and Nayak, S. (2008) Soil-Leachate Interaction and Their Effects on Hydraulic Conductivity and Compaction Characteristics. The 12th International Conference of International Association for Computer Methods and Advances in Geomechanics, 1-6 October.

Uppot, J.O., Stephenson, R.W. 1989. Permeability of clays under organic permeants. Journal of Geotechnical Engineering, 115(1):115-131. 